\title{
Guinea Negro: A High-Yielding Out-of-Season Yam Cultivar ${ }^{1}$
}

\author{
O. D. Ramirez, J. J. Green, and I. B. Caloni ${ }^{2}$
}

\begin{abstract}
Guinea Negro, a yam cultivar introduced from Jamaica, belongs to the same genus and species as Habanero (Dioscorea rotundata Poir). After various experiments it was found to be high yielding and with a shorter dormant period than that of Habanero. It can be planted out of season for high yields. When planted in October, and harvested at 7 (May), 8 (June), and 9 (July) months, it yielded 45, 50 and 53 tons/ha, respectively. Using both cultivars, that is, planting Habanero in its regular season, and Guinea Negro out of season, there would be yams on the market all year round.
\end{abstract}

\section{INTRODUCTION}

Root crops are a very important source of carbohydrates in the diet of many Puerto Ricans. Among yams, cassava, sweet potato and taniers, yams are the most important. According to González Villafañe et al. (5), yam production in Puerto Rico has fluctuated between 250,000 to 300,000 cwt. yearly, and its value at the farm level has increased from $\$ 404,000$ to $\$ 5.8$ million.

At present, our yam production depends mostly on one variety, Habanero (Dioscorea rotundata Poir) $(3,4)$. Florido (D. alata L.) (3) used to be our main variety, but because of its susceptibility to a fungus known as "candelilla," it has been supplanted by Habanero, which is not attacked by this disease.

In our search for better varieties or cultivars, new introductions are propagated and evaluated as to adaptability to our conditions, yield potential, disease resistance and quality.

In the yams grown in Puerto Rico, dormancy normally occurs during the winter months; for that reason, the normal planting season is during the months of January to May, with yams on the market from August to February (fig. 1). Yams are ready for harvesting from 8 to 11 months after planting (6).

Demand for the product forces the farmer to harvest yams prematurely. To extend their availability the farmer does what is known as milking, which is a premature harvesting of each plant, leaving the root system

${ }^{1}$ Manuscript submitted to Editorial Board December 13, 1982.

${ }^{2}$ Plant Breeder, Horticulture Department, Agricultural Experiment Station, University of Puerto Rico, Río Piedras; Assistant Horticulturist, Corozal Substation; and Associate Food Technologist, Food Technology Laboratory, Agricultural Experiment Station, University of Puerto Rico, College of Agricultural Sciences, Mayagüez Campus, Río Piedras, P. R. 


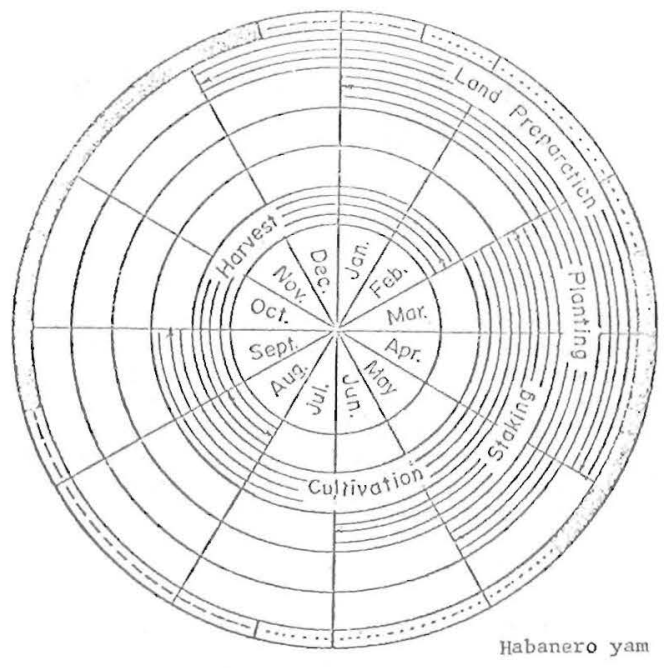

RAINFALL
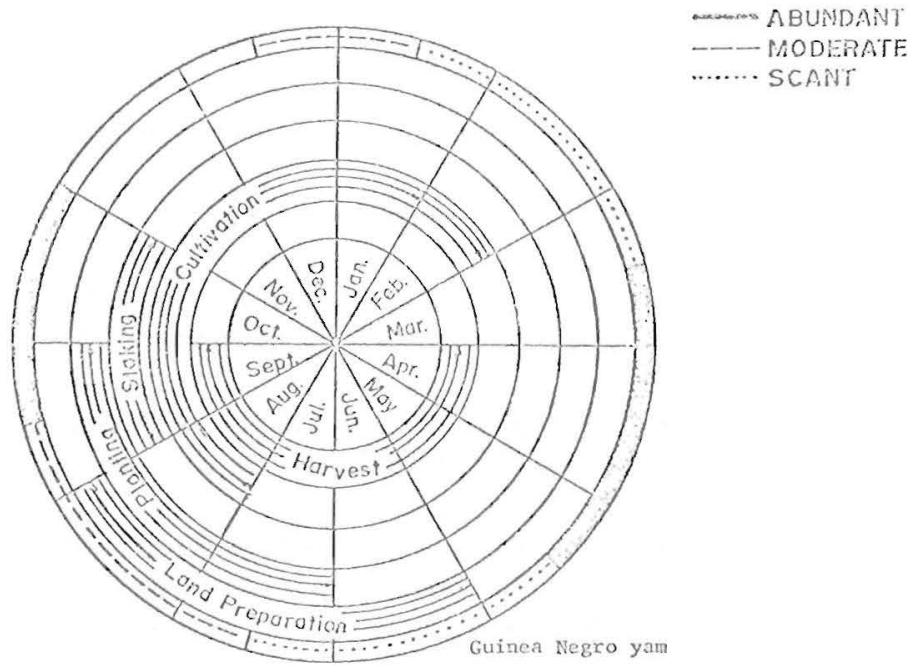

FIG. 1.-Pattern of rainfall and distribution of agronomic practices in Habanero and Guinea Negro yams during the year at Corozal, Puerto Rico.

undisturbed. This milking occurs in August. Thus the harvest starts in August and lasts until February. There are no yams on the market during spring and summer, when there is a big demand for the product.

In our effort to solve these problems, variety trials with yams are being carried out. In a preliminary trial, a very promising yam was selected. This yam, known as "Guinea Negro," was introduced from Jamaica. This 
paper presents the results obtained in various trials as compared with those of "Guinea Blanco (Habanero)."

\section{MATERIALS AND METHODS}

Two yam cultivars of Dioscorea rotundata (Poir.) $(3,4)$ were tested in four experiments. These were "Habanero," a yam cultivar common in Puerto Rico and well accepted by our people, and "Guinea Negro," a cultivar introduced from Jamaica.

The various experiments were planted at the Corozal substation on a Corozal clay (Ultisol) from 1977 to 1980. In these experiments various planting distances were used. Populations varied from 6,500 to 12,500 plants per acre $(1,2)$.

An experiment was planted February 1977 in a split-plot design, in which the variety was the main plot and the time of harvest the subplot. Three harvests were tested: at 8, 9 and 10 months.

The second experiment was planted December 1978 and harvested at 9,10 and 11 months. In the third experiment, the time of planting was changed in accordance to the dormancy of the variety. Cultivar Guinea Negro, which was observed as having a short dormant period, was planted January 1980, while cultivar Habanero was planted March 1980. Both cultivars were harvested 9 months after planting.

Sensory evaluation of Guinea Negro yam was carried out by a panel. This poll was based on a six-point hedonic scale (7) ranging from "like very much" to "dislike."

The fourth experiment was planted and harvested out of season. It was planted October 1980 and harvested 7, 8 and 9 months after planting.

In all the experiments the agronomical practices recommended by the Agricultural Experiment Station of the University of Puerto Rico (2) were followed.

\section{RESULTS AND DISCUSSION}

Table 1 shows the results obtained from the four experiments in which the two yam cultivars were tested.

There was no significant difference as to yield and time of harvest in experiments 1 and 2. In the February planting, yield was higher in Guinea Negro than in Habanero at all three harvesting times. The highest yield was obtained at 9 months, 33.78 tons/ha, which is equivalent to 301.66 cwt/acre. This yield compares favorably with the average yield reported by González Villafañe (5) for Habanero, $124.84 \mathrm{cwt} /$ acre in 1979. Also at 8 and 10 months after planting, the yields obtained with Guinea Negro were higher than the average yield reported for Habanero.

In experiment 2 , the yield of both varieties was lower than that 
obtained in experiment 1 . There is a possibility that this decrease might be due to the time of planting: one experiment was planted in February; the other in December.

From this data we concluded that in terms of yield, both varieties behaved similarly when planted in December. It was also observed that Guinea Negro requires a shorter development period. Its yield was higher at 9 months, whereas in Habanero highest yield was at 11 months.

TABLE 1.-Estimated marketable yield of Guinea Negro and Habanero yams at various planting seasons

\begin{tabular}{|c|c|c|c|c|c|c|c|}
\hline \multirow[b]{2}{*}{ Cultivar } & \multirow[b]{2}{*}{ Planting time } & \multicolumn{2}{|c|}{ Harvesting } & \multicolumn{4}{|c|}{ Yield } \\
\hline & & Months & Time & $\begin{array}{c}\text { Mean } \\
\text { lb }\end{array}$ & Cwt/acre & $\begin{array}{c}\text { Tons/ } \\
\text { acre }\end{array}$ & Tons/ha \\
\hline \multicolumn{8}{|c|}{ Experiment 1} \\
\hline \multirow[t]{3}{*}{ Guinea Negro } & Feb. 1977 & 8 & Sept. 1978 & 36.98 & 244.06 & 12.20 & 27.33 \\
\hline & Feb. 1977 & 9 & Oct. 1978 & 26.59 & 301.63 & 15.08 & 33.78 \\
\hline & Feb. 1977 & 10 & Nov. 1978 & 27.18 & 197.32 & 9.86 & 22.10 \\
\hline \multirow[t]{4}{*}{ Habanero } & Feb. 1977 & 8 & Sept. 1978 & 13.68 & 102.81 & 5.14 & 11.51 \\
\hline & Feb. 1977 & 9 & Oct. 1978 & 17.43 & 210.90 & 10.54 & 23.62 \\
\hline & Feb. 1977 & 10 & Nov. 1978 & 11.01 & 121.11 & 6.05 & 13.56 \\
\hline & & & Experiment 2 & & & & \\
\hline \multirow[t]{3}{*}{ Guinea Negro } & Dec. 1978 & 9 & Sept. 1979 & 32.33 & 112.34 & 5.62 & 12.58 \\
\hline & Dec. 1978 & 10 & Oct. 1979 & 42.00 & 147.54 & 7.37 & 16.52 \\
\hline & Dec. 1978 & 11 & Nov. 1979 & 44.83 & 147.93 & 7.40 & 16.57 \\
\hline \multirow[t]{4}{*}{ Habanero } & Dec. 1978 & 9 & Sept. 1979 & 30.58 & 118.93 & 5.95 & 13.32 \\
\hline & Dec. 1978 & 10 & Oct. 1979 & 30.67 & 122.16 & 6.11 & 13.68 \\
\hline & Dec. 1978 & 11 & Nov. 1979 & 28.83 & 177.77 & 8.88 & 19.91 \\
\hline & & & Experiment 3 & & & & \\
\hline Guinea Negro & Jan. 1980 & 9 & Sept. 1980 & 58.41 & 246.91 & 12.34 & 27.65 \\
\hline \multirow[t]{2}{*}{ Habanero } & March 1980 & 9 & Nov. 1980 & 25.63 & 179.48 & 8.97 & 20.10 \\
\hline & & & Experiment 4 & & & & \\
\hline \multirow[t]{3}{*}{ Guinea Negro } & Oct. 1980 & 7 & May 1981 & 264.50 & 400.05 & 20.00 & 44.80 \\
\hline & Oct. 1980 & 8 & June 1981 & 303.50 & 447.39 & 22.37 & 50.10 \\
\hline & Oct. 1980 & 9 & July 1981 & 305.14 & 473.86 & 23.69 & 53.07 \\
\hline
\end{tabular}

In the first experiment, Guinea Negro, was planted in January, when it started to sprout; Habanero was planted in March. This in an indication that Guinea Negro's physiological behavior is different from that of Habanero.

Yield of Guinea Negro was 27.65 tons/ha; yield of Habanero was 20.10 tons/ha. This difference of 7.45 tons/ha was highly significant.

Thus we have an increase in yield and at the same time an increase in selling price because other yams are not available.

Table 2 shows that Guinea Negro yam was well accepted by the tasting panel in all attributes evaluated (5.11 out of 6), an indication that Guinea Negro is a very promising yam variety. 
Taking advantage of Guinea Negro's characteristic shorter dormancy period, we planned our next experiment so that harvest would be off the normal yam season.

The results obtained in the fourth experiment are promising because the yams were harvested out of season without the need for milking the plants.

No significant differences were observed as to yield and number of tubers per plant at the different harvest times, 7, 8 and 9 months after planting. Only the average yield per plant was significantly higher at the $5 \%$ level in the 9 -month harvest as compared to those at 7 and 8 months. In each of the harvests, May ( 7 months), June ( 8 months) and July (9 months), the yield per acre was higher than $360 \mathrm{cwt}$, a good yield for Habanero. During these months the farmers obtain higher prices because of the scarcity of other yams.

TABLE 2.-Results of sensory evaluation of a new variety of yam (Guinea Negro) by appearance, flavor, texture, and overall acceptability

\begin{tabular}{lcccc}
\hline \multirow{2}{*}{ Cultivar } & \multicolumn{4}{c}{ Mean values $^{1}$} \\
\cline { 2 - 5 } & Appearance & Flavor & Texture & $\begin{array}{c}\text { Overall } \\
\text { acceptability }\end{array}$ \\
\hline Guinea Negro & 5.28 & 5.17 & 5.06 & 5.11 \\
\hline
\end{tabular}

${ }^{1} 6$-point hedonic scale (6-like very much; 5 -like; 4-like moderatedly 3 -neither like nor dislike; 2-dislike a bit; 1-dislike.)

This experiment suggests that by planting both cultivars, Guinea Negro and Habanero (fig. 1), the former out of season, and the other during the regular season, and by using the agronomical practice of milking, we can produce yam all year round, thus controlling yam importation; furthermore, the farmer can obtain a better price for his product.

Because the dormant period of Guinea Negro is shorter than that of Habanero, it cannot be stored for a long period of time. It will start sprouting 2 or 3 months after harvest. When this sprouting takes place, it has to be planted immediately.

\section{RESUMEN}

En la subestación de Corozal se sembraron varios experimentos en los que se probaron dos cultivares de ñame de la especie $D$. rotundata. Estos son Guinea Negro y Habanero. Dichos experimentos se sembraron en la época normal en la que se siembra el ñame y fuera de esta época. Se encontró que la cultivar conocida como Guinea Negro es una buena productora. El rendimiento obtenido fue más alto que el del ñame Habanero. La característica más sobresaliente de este ñame es que se puede sembrar fuera de época ya que su latencia es muy corta. Siembras hechas 
en octubre con este ñame se cosecharon a los 7,8 y 9 meses con rendimientos de 45,50 y 53 toneladas/ha, respectivamente, cuando no hay ñames en el mercado.

\section{LITERATURE CITED}

1. Caro-Costas, R., Boneta, E. and Silva, S., 1968. Effect of various cultural practices on yields of yams in Puerto Rico, J. Agric. Univ. P. R. 52 (4): 356-61.

2. Conjunto Tecnológico para la Producción de Cosechas Farináceas, 1976. Publ. 101, Esta. Exp. Agric. Univ. P.R.

3. Coursey, D. G., 1967. Yams, Longmans, Green and Co., Ltd.

4. Espinet, G. R., 1972. Costos y Prácticas en la Producción del Ñame (Dioscorea spp.) en Puerto Rico, 1967-68, Publ. 78, Esta. Exp. Agric. Univ. P. R.

5. González-Villafañe, E., Espinet, G. R. and Troche, J. L., 1980. Análisis Económico de la Producción del Ñame en Puerto Rico, Publ. 132, Esta. Exp. Agric. Univ. P. R.

6. Ingram, J. S. and Greenwood-Barton, L. H., 1962. The cultivation of yams for food, Trop. Sci. 4: 82-6.

7. Pergam, D. R. and Pilgrim, F. J., 1957. Hedonic scale method for measuring food preferences, Food Technol. 11 (9): Insert 9. 